\title{
PENERAPAN LKPD TERBIMBING UNTUK MENINGKATKAN KETERAMPILAN PRAKTIKUM PESERTA DIDIK
}

* Christine Widya Puspamareta

Universitas Negeri Makassar christinewidyapm@gmail.com

Kaharuddin Arafah Universitas Negeri Makassar Kaharuddinarafah@unm.ac.id

Muh. Sidin Ali Universitas Negeri Makassar sidinali@unm.ac.id

*koresponden author
Abstrak - Penelitian ini merupakan penelitian pre-experiment dengan menggunakan desain One Group Pretest Posttest design. Subjek penelitian sebanyak 23 orang pada kelas X MIA 9. Berdasarkan analisis skor pretest dan posttest dengan menggunakan uji n-gain maka diperoleh 39,1\% termasuk dalam kategori sedang dan $60,9 \%$ termasuk dalam kategori tinggi. Hasil ini menunjukkan bahwa peningkatan keterampilan praktikum peserta didik dengan menggunakan LKPD Terbimbing termasuk dalam kategori tinggi

Kata Kunci : : Lembar Kerja Terbimbing, Keterampilan Praktikum

Abstract - This study was pre-experiment with Group Pretest Posttest design design. Research subjects were 23 people in class X MIA 9. Based on the analysis of Pretests and posttest scores using N-Gain test, $39.1 \%$ is included in medium category and 60.9\% belongs to high category. These results suggest that the improvement of the students practicum skills by using the guided LKPD belongs to the high category.

Keywords : guided worksheet, practicum skills. 


\section{A. PENDAhuluan}

Pendidikan merupakan salah satu aspek penting dalam perkembangan suatu negara. Pendidikan mampu menciptakan Sumber Daya Manusia (SDM) yang berkualitas, sehingga mampu mendukung perkembangan suatu negara. Negara berkembang memiliki keyakinan, bahwa pendidikan adalah kunci utama menuju kebahagiaan dan perlindungan ekonomi di masa yang akan datang.

Menurut Undang-Undang Nomor 20 Tahun 2003 tentang Sistem Pendidikan Nasional, Pasal 1 ayat 1 menyatakan bahwa pendidikan adalah usaha sadar dan terencana untuk mewujudkan suasana belajar dan proses pembelajaran agar peserta didik secara aktif mengembangkan potensi dirinya untuk memiliki kekuatan spiritual keagamaan, pengendalian diri, kepribadian, kecerdasan, akhlak mulia, serta ketrampilan yang diperlukan dirinya, masyarakat, bangsa dan negara.

Fisika merupakan salah satu mata pelajaran yang merupakan bagian dari Ilmu Pengetahuan Alam (IPA). Fisika mempelajari gejala-gejala yang terjadi di alam sekitar. Dalam mempelajari ilmu fisika, bukan hanya berbicara mengenai teori atau konsep. Melainkan, orang yang mempelajari fisika , diharapkan mempunyai sebuah keterampilan. Keterampilan ini dimaksudkan sebagai aplikasi untuk memahami teori yang telah dipelajari. Sebagai ilmu sains, keterampilan tersebut dinamakan sebagai keterampilan proses sains.

Salah satu indikator keterampilan proses sains adalah merencanakan percobaan melalui kegiatan praktikum. Kegiatan praktikum ini dimaksudkan untuk mengaplikasikan teori yang telah diterima siswa di dalam kelas. Karena pengetahuan yang diperoleh di kelas tidaklah cukup untuk meningkatkan keterampilan proses sains siswa. Praktikum dalam suatu ilmu alam, sangat penting adanya, karena dianggap sebagai suatu cara yang bisa meningkatkan keyakinan mengenai konsep atau teori yang ada. Adanya praktikum akan memperlihatkan bagaimana siswa-siswa bisa terampil dalam segala hal untuk mewujudkan keterampilan proses sains tadi.

Menurut Notoadmodjo (2007) keterampilan merupakan aplikasi dari pengetahuan sehingga tingkat keterampilan seseorang berkaitan dengan tingkat pengetahuan. Kegiatan praktikum merupakan bagian yang tidak terpisahkan dalam pembelajaran IPA khususnya Fisika, sehingga IPA disebut dengan experimental science. Hal itu sejalan dengan praktikum ini berarti peserta didik diberi kesempatan untuk mengalami sendiri, mengikuti proses, mengamati suatu objek, menganalisisi, membuktikan, dan menarik kesimpulan sendiri tentang suatu objek, keadaan atau proses sesuatu.

Darmodjo \& Kaligis (1992:40) menyatakan bahwa salah satu sarana yang di gunakan untuk mengoptimalkan keterlibatan atau aktifitas peseta didik dalam pembelajaran adalah dengan menggunakan LKPD. Lembar kerja peserta didik LKPD yang disusun dapat dirancang dan dikembangkan sesuai dengan kondisi dan situasi kegiatan pembelajaran yang akan dihadapi (Rchaeti,LFX, \& Padmaningrum, 2009). Dalam skripsi ini akan menggunakan LKPD berbasis inkuiri terbimbing.

LKPD berbasis inkuiri merupakan LKPD yang dapat melatih keterampilan proses sains peserta didik karena dalam langkah-langkah inkuiri terdapat komponen keterampilan proses sains yang ingin ditingkatkan (Islami, Khaeruddin, \& Aziz, 2019). Ketika siswa telah menemukan sendiri konsep materi yang sedang dipelajari, maka diharapkan siswa akan dapat menerapkan konsep tersebut dalam menyelesaikan soal-soal yang berkaitan dengan materi tersebut. Diharapkan nantinya aktivitas dan hasil belajar siswa dapat meningkat. Guru banyak mengarahkan dan memberikan petunjuk. Petunjuk tersebut 
dapat berupa pertanyaan yang bersifat membimbing, atau dapat pula berupa penjelasan seperlunya saat peserta didik akan melakukan percobaan (Annafi \& Mulyani, 2015).

Dalam pembelajaran menggunakan LKPD terbimbing ini guru berperan sebagai petunjuk kerja baik melalui prosedur yang lengkap dan pertanyaan pengarah selama proses penyelidikan. Dalam model inkuiri terbimbing, campur tangan guru lebih besar sehingga kesimpulan lebih cepat dan lebih mudah diambil. Kegiatan belajar yang banyak berhubungan dengan ranah psikomotorik adalah praktik di aula/lapangan, bengkel, dan praktikum di laboratorium. Dalam hubungan ini guru melakukan pengamatan untuk menilai dan menentukan apakah siswa sudah terampil atau belum, memerlukan kerja sama kelompok di nilai keterampilan kerja sama peserta didik serta keterampilan kepemimpinan siswa dan lain sebagainya. Motivasi dan arahan yang diberikan oleh guru kepada peserta didik adalah faktor yang paling dominan berpengaruh terhadap meningkatnya pencapaian psikomotorik peserta didik (Asyhari, Surano \& Sarwanto,2014).

Berdasarkan hasil observasi yang di lakukan di SMA Negeri 9 Makassar, salah satu media yang sering digunakan dalam proses pembelajaran kelas X di SMAN 9 Makassar adalah Lembar Kegiatan Peserta Didik (LKPD). LKPD yang digunakan adalah LKPD yang monoton yaitu berupa LKPD dengan tampilan kurang menarik, hanya berisi teks tanpa gambar dan terdapat pertanyaan yang kurang melatih keterampilan praktikum sehingga pada saat di gunakan oleh peserta didik dalam praktikum, mereka kurang termotivasi, hal ini juga mengakibatkan bahwa keterampilan praktikum peserta didik rendah. Guru mata pelajaran fisika di sekolah ini tidak membuat sendiri LKPD untuk digunakan dalam praktikum, melainkan mereka membeli di percetakan. Berdasarkan pemaparan diatas, maka peneliti tertarik untuk mengetahui gambaran keterampilan praktikum siswa yang terbentuk melalui penggunaan Lembar Kerja Peserta Didik Berbasis Inkuiri Terbimbing. Sehingga penelitian ini mengangkat judul "Penerapan Lembar Kerja Peserta Didik (LKPD) Terbimbing untuk Meningkatan Keterampilan Praktikum Peserta Didik Kelas X SMA Negeri 9 Makassar

\section{B. METODE}

Penelitian ini merupakan penelitian pre-exsperiment. Penelitian dilaksanakan pada semester genap tahun pelajaran 2018/2019 di SMA Negeri 9 Makassar, Jalan Karunrung Raya No. 37, Kecamatan Rappocini, Kota Makassar. Sampel dalam penelitian ini adalah 23 orang peserta didik kelas X MIA 9. Variabel penelitian ini adalah lembar kerja peserta didik terbimbing dan keterampilan praktikum. Definisi Lembar kerja peserta didik terbimbing adaah salah satu sumber belajar yang disusun dan dikembangkan sedemikian rupa yang berisi petunjuk dan langkah-langkah di dalam melakukan praktikum fisika, dimana prosedur kerja atau langkah-langkah kegiatan praktikum tersebut di sajikan dalam bentuk LKPD terbimbing sehingga siswa dapat mengembangkan pengetahuannya dan keterampilan praktikum. Dan Keterampilan praktikum dalam penelitian ini yaitu kecakapan peserta didik dalam melakukan kegiatan praktikum yang ditinjau dari beberapa indikator diantaranya, indikator membaca skala, menggunakan alat ukur, merangkai alat, pengabilan data, dan menuliskan hasil percobaan. Adapun design penelitian ini adalah One Group Pretest Posttest design.

Teknik pengumpulan data menggunakan instrumen non test yaitu lembar observasi untuk mengukur keterampilan peserta didik dalam melaksanakan praktikum. Lembar observasi bertujuan untuk melihat apakah setiap tahapan-tahapan praktikum peserta didik memiliki kemajuan dalam melakukan praktikum. Lembar observasi telah dibuat dan dikonsultasikan dengan dosen pembimbing 
selanjutnya akan dilakukan uji validitas Gregory atau uji validitas isi. Uji validitas Gregory merupakan pengujian valid atau tidaknya suatu instrumen yang dilakukan oleh dua atau lebih pakar/ahli. Teknik analisis data yang akan digunakan dalam penelitian ini adalah analisis deskriptif dan teknik analisis yang digunakan untuk melihat peningkatan keterampilan praktikum peserta didik yaitu dengan menggunakan teknik analisis statistik $\mathrm{N}-$ Gain score.

\section{HASIL DAN PEMBAHASAN}

Lembar Kerja Peserta Didik berbasis inkuiri terbimbing mengajak siswa untuk menemukan sendiri konsep materi yang sedang dipelajari (Hamidah, Haryani, \& Wardani, 2018). Keterampilan praktikum peserta didik dinilai menggunakan instrumen penilaian berupa lembar observasi yang terdiri dari beberapa kategori. Hasil penilaian pada pertemuan pertama sebelum diberikan perlakuan diambil sebagai skor pretest dan hasil observasi pada pertemuan terakhir setelah diberikan perlakuan diambil sebagai skor posttest. Adapun keterampilan praktikum peserta didik dikemukakan dalam bentuk analisis deskriptif adalah nilai pretest dan posttest peserta didik kelas X MIA 9 SMAN 9 Makassar tahun ajaran 2018/2019.

Tabel 1. Analisis Deskriptif Skor Pretest dan Posttest pada Keterampilan Praktikum Peserta Didik Kelas X MIA 9 Makassar Tahun Ajaran 2018/2019.

\begin{tabular}{lcc}
\hline \multicolumn{1}{c}{ Statistik } & Pretest & Posttest \\
\hline Jumlah sampel (N) & 23 & 23 \\
Skor maksimum & 12 & 18 \\
Skor minimum & 2 & 14 \\
Skor Ideal & 20 & 20 \\
Skor rata-rata ( $\bar{x})$ & 7,3 & 16,5 \\
Varians (S & 7,3 & 1,8 \\
Standar deviasi (S) & 2,7 & 1,3 \\
\hline
\end{tabular}

Tabel 1 di atas untuk pretest menunjukkan skor rata-rata peserta didik 7,3 sedangkan posttest menunjukkan skor 16,5 dimana skor rata-rata yang diperoleh pada saat Pretest lebih tinggi dibanding pada saat pretest. Sedangkan untuk skor varians pada pretest menunjukkan skor 7,3 sedangkan posttest dicapai hanya 1,3 .

Tabel 2 Pengkategorian Skor Pretest dan Posttest Keterampilan Praktikum Peserta Didik Kelas X

SMAN 9 Makassar

\begin{tabular}{cccccc}
\hline Interval & Kategori & \multicolumn{2}{c}{ Pretest } & \multicolumn{2}{c}{ Posttest } \\
nilai & & Frekuensi & Pre (\%) & Frekuensi & Pre (\%) \\
\hline $\mathbf{1 9 - 2 2}$ & Sangat tinggi & 0 & 0 & 1 & 4,3 \\
$\mathbf{1 4 - 1 8}$ & Tinggi & 0 & 0 & 22 & 95,7 \\
$\mathbf{1 0 - 1 3}$ & Cukup & 4 & 17,4 & 0 & 0 \\
$\mathbf{6 - 9}$ & Rendah & 14 & 60,9 & 0 & 0 \\
$\mathbf{2 - 5}$ & Sangat rendah & 5 & 21,7 & 0 & 0 \\
& Jumlah & & 23 & 100,00 &
\end{tabular}

Tabel 2 di atas menunjukkan bahwa pada pretest dari 23 peserta didik yang menjadi subjek penelitian, persentase skor keterampilan praktikum yang berada pada kategori rendah yaitu 60,9\% sedangkan persentase skor keterampilan praktikum pada posttest yang berada pada kategori tinggi yaitu 95,7\% artinya pada saat posttest persentase skor keterampilan praktikum lebih besar dibanding pada saat pretest. 


\section{Analisis n-gain score pada peningkatan keterampilan praktikum}

Tabel 4.6 Distribusi Frekuensi N-Gain Skor pada Peningkatan Keterampilan Praktikum Peserta Didik Kelas X MIA 9 SMAN 9 Makassar Tahunn Ajaran 2018/2019

\begin{tabular}{cccc}
\hline Interval nilai & Kategori & Frekuensi & $\begin{array}{c}\text { Presentase } \\
\text { (\%) }\end{array}$ \\
\hline $\mathbf{g}>\mathbf{0 , 7}$ & Tinggi & 14 & 60,9 \\
$\mathbf{0 , 3 1 -}$ & Sedang & 9 & 39,1 \\
$\mathbf{0 , 7 0}$ & & & \\
$\mathbf{0 , 0 0 - 0 , 3 0}$ & Rendah & 0 & 0
\end{tabular}

Secara keseluruhan, kemampuan keterampilan praktikum peserta didik kelas X MIA 9 SMA Negeri 9 Makassar dalam kategori tinggi. Hal ini diketahui setelah peneliti melakukan analisis deskriptif dan uji N-gain pada hasil pengamatan. Kegiatan praktikum dilaksanakan di laboratorium fisika pada peserta didik kelas X MIA 9 SMAN 9 Makassar selama 3 pekan, yang terbagi atas 1 pekan untuk pretest dan 2 pekan untuk melakukan perlakuan beserta posttest.

Pertemuan pertama sekaligus dilakukan pretest dalam penelitian ini dimana guru mengajarkan peserta didik mengenai materi Gerak Harmoni Sederhana (GHS). Selanjutnya pendidik dibantu oleh peneliti membagi peserta didik menjadi empat kelompok dan membagikan masing-masing kelompok LKPD biasa "Gerak Harmonik Pada Bandul” yang telah disiapkan oleh peneliti. Peneliti dibantu oleh satu orang observer untuk melakukan observasi awal (pretest) kepada setiap peserta didik yang melakukan praktikum menggunakan LKPD yang telah dibagikan.

Pada pertemuan pertama ini, peneliti beserta observer hanya melakukan observasi dan mengisi lembar observasi yang telah dibuat, dimana tidak ada perlakuan yang diberikan kepada peserta didik. Dari hasil observasi yang dilakukan dapat dilihat bahwa keterampilan praktikum peserta didik masih dalam kategori rendah, pada pertemuan pertama (pretest) peserta didik melakukan percobaan bandul sederhana. Dimana dari hasil pretest keterampilan praktikum peserta didik diketahui bahwa terdapat beberapa indikator penilaian yang belum mereka kuasai seperti, pada indikator menggunakan alat ukur, indikator keterampilan praktikum yang belum dikuasai peserta didik yaitu memeriksa kelengkapan alat dan bahan praktikum yang akan digunakan, dimana pada saat praktikum peserta didik langsung saja menggunakan alat ukur tanpa memeriksa terlebih dahulu apakah alat dan bahan yang akan mereka gunakan telah tersedia semua. Kemudian indikator keterampilan praktikum membaca skala, saat mengamati percobaan pandangan mata peserta didik tidak sejajar dengan alat ukur yang mereka gunakan dalam hal ini busur. Pada saat menentukan sudut yang akan digunakan.

Adapun indikator yang dominan yang dikuasai oleh peserta didik yaitu indikator melakukan praktik atau pada saat pengambilan data, dimana peserta didik teliti dalam melakukan praktik sesuai dengan prosedur yang ada, tekun dalam melakukan praktik, dan setiap kelompok bekerja sama dengan baik pada saat melakukan praktikum. Sehingga secara keseluruhan keterampilan praktikum peserta didik termasuk dalam kategori rendah setelah dilakukan analisis statistik deskriptif.

Pertemuan kedua sampai keenam peneliti menerapkan lembar kerja peserta didik terbimbing yang telah diajukan oleh peneliti. Lembar kerja peserta didik terbimbing adalah suatu perangkat yang digunakan pada saat melakukan praktikum dimana langkah-langkah percobaan, peralatan dan objek yang digunakan serta seluruh percobaan telah dirancang oleh pendidik. Pada pertemuan kedua dilakukan perlakuan $\left(\mathrm{X}_{1}\right)$ pada peserta didik, peneliti dibantu observer memberikan penjelasan 
mengenai lembar kerja peserta didik terbimbing yang akan mereka gunakan, kemudian dimulailah percobaan. Saat berlangsungnya praktikum peserta didik diobservasi untuk melihat keterampilan praktikumnya. Dimana peserta didik diberikan perlakuan (treatment) dimana peserta didik diajar atau dibimbing menggunakan alat ukur yang benar, merangkai alat, dan menuliskan hasil percobaan dengan benar. Peneliti dibantu oleh observer untuk memberikan perlakuan kepada setiap peserta didik yang akan melakukan praktikum.

Pada pertemuan ketiga $\left(\mathrm{X}_{2}\right)$ dan keempat $\left(\mathrm{X}_{3}\right)$, peneliti beserta observer mengulangi pola pembimbingan yang sebelumnya telah dilakukan. Yang terkadang peserta didik masih banyak yang bertanya tentang bagaimana merangkai alat dengan benar, menggunakan alat ukur dan menuliskan hasil percobaan. Berdasarkan dari hasil observasi yang dilakukan pada pertemuan ini, perlahan-lahan kemampuan peserta didik dalam melakukan praktikum mengalami perubahan yang awalnya mereka tidak tahu dan tidak dapat melakukan sendiri percobaan sehingga mereka bisa melakukannya tanpa banyak diajarkan atau diberitahu oleh peneliti dan observer. Dan juga peserta didik pada mulai tekun dan semangat saat melakukan percobaan.

Pada pertemuan kelima menggunakan LKPD terbimbing kemampuan peserta didik dalam melakukan praktikum dapat dilihat memuaskan, karena peserta didik langsung melakukan praktikum sesuai dengan yang diajarkan pada pertemuan-pertemuan sebelumnya. Apabila mereka lupa atau ada yang tidak dimengerti baru mereka kembali bertanya kepada peneliti dan observer. Hal ini menunjukkan bahwa perlakuan selama empat kali dilakukan dapat dikatakan berhasil untuk meningkatkan keterampilan praktikum peserta didik. Dari hasil observasi yang dilakuan peneliti dan observer pada setiap pertemuan, walaupun pada setiap indikator ada saja yang tidak dilakukan oleh peserta didik.

Pada pertemuan keenam maka selanjutnya dilakukan posttest dengan cara penilaian dengan menggunakan lembar observasi, dari hasil posttest didapatkan 23 orang peserta didi berada pada kategori tinggi. Melihat dari hasil observasi di atas indikator keterampilan praktikum dominan yang belum mereka kuasai yaitu indikator menuliskan hasil percobaan dalam hal ini peserta didik kesulitan dalam mengidentifikasi variabel-variabel yang dapat mempengaruhi hasil praktikum dengan benar. Sedangkan indikator yang dominan peserta didik kuasai yaitu pertama, indikator membaca skala, pada saat mengamati percobaan pandangan mata peserta didik sejajar dengan alat ukur yang digunakan dan peserta didik mampu membaca petunjuk skala alat ukur dengan benar. Yang kedua, indikator menggunakan alat ukur, dimana peserta didik menggunakan alat ukur sesuai dengan fungsinya dan pengukuran dilakukan dengan menempatkan alat ukur pada benda yang akan diamati. Peserta didik tekun pada saat melakukan praktikum dan melakukan percobaan sesuai dengan prosedur kerja yang ada.

Dari kedua hasil observasi pretest dan posttest dapat diketahui bahwa terjadi peningkatan keterampilan praktikum, hal ini dilihat dari kemampuan peserta didik yang mengalami perubahan dari setiap pertemuan pada saat mlakukan percobaan di laboratorium yaitu tercapainya indikator perilaku peserta didik. Sehingga dengan demikian dapat diketahui bahwa dengan menggunakan LKPD terbimbing ini dapat meningkatkan keterampilan praktikum peserta didik. Hal ini sesuai dengan penelitian yang pernah dilakukan oleh Wiwin, dkk (2013), dimana dalam penelitiannya menemukan bahwa pembelajaran inkuiri terbimbing memberikan pengaruh yang signifikan terhadap keterampilan 
proses sains karena pembelajaran inkuiri terbimbing tersebut melibatkan proses secara ilmiah melalui eksperimen untuk membuktikan kebenaran suatu materi yang dipelajari.

Selain itu faktor yang mempengaruh ialah peserta didik belum terbiasa menggunakan LKPD terbimbing yang berbeda dengan LKPD yang biasa mereka gunakan. Hal tersebut sejalan dengan pernyataan Siti Meilani (2017) bahwa pembiasaan pembelajaran dengan metode latihan paktikum terbimbing menyebabkan adanya perkembangan kemampuan dalam meningkatkan keterampilan praktikum peserta didik.

Penelitian ini pemberian perlakuan atau pengetahuan tambahan kepada peserta didik memberikan sumbangsi yang lebih besar dalam meningkatkan keterampilan praktikum selain dari pada penggunaan LKPD terbimbing itu sendiri, sesuai dengan pernyataan Wahyudiati (2018) dalam penelitiannya mengenai melakukan persiapan sebelum memulai kegiatan praktikum yang bertujuan untuk memudahkan melaksanakan kegiatan praktikum karena persiapan pelaksanaan praktikum merupakan tahap yang sangat penting dalam menentukan keberhasilan suatu praktikum. Hasil penelitian terdahulu bahwa pembelajaran melalui LKPD berbasis inkuiri terbimbing memberikan pengalaman-pengalaman dalam belajar. Peserta didik berpartisipasi aktif menghadapi pembelajaran sehingga dapat menimbulkan motivasi peserta didik untuk belajar

\section{SIMPULAN (JIKA ADA)}

Berdasarkan hasil analisis dan pembahasan yang telah dikemukakan, maka dapat ditarik kesimpulkan bahwa keterampilan praktikum peserta didik dengan menggunakan lembar kerja peserta didik kelas X MIA 9 SMAN 9 Makassar Tahun Ajaran 2018/2019 berada dalam kategori tinggi yaitu sebesar $60,9 \%$ setelah diberikan perlakuan menggunakan lembar kerja peserta didik terbimbing tersebut.

\section{DAFTAR RUJUKAN}

Ambarsari, Wiwin., Santosa, Slamet, Maridi. 2013 Penerapan Pembelajaran Inkuiri Terbimbing Terhadap Keterampilan Proses Sains Dasar Pada Pelajaran Biologi Siswa Kelas VIII SMP Negeri 7 Surakarta, Jurnal Pendidikan Biologi, Vol. 5, No 1.

Annafi, N., \& Mulyani, A. d. (2015). Pengembangan Lembar Kegiatan Peserta Didik Berbasis Inkuiri Terbimbing Pada Materi Termokimia Kelas XI SMA/MA. 4(3): 21-28.

Asyhari, A., Surano, W., \& Sarwanto. (2014). Pengembangan Perangkat Pembelajaran Fisika Berbasis Inkuiri Terbimbing Terintegrasi Pendidikan Karakter. 3(I): 62-75.

Depdiknas. (2008). Undang-Undang Tentang Sistem Pendidikan Nasional. Jakarta: Depdiknas.

Gregory, R. J. (2015). Psychological Testing: History, Principles, and Applications. England: Pearson Education Limited.

Hamidah, N., Haryani, S., \& Wardani, S. (2018). Efektivitas Lembar Kerja Peserta Didik Berbasis Inkuiri Terbimbing Untuk Meningkatkan Hasil Belajar Siswa. Jurnal Inovasi Pendidikan Kimia, Vol 12, No 2, 2212 - 2223.

Hendro Darmodjo dan Jenny R.E Kaligis. 1993. Pendidikan IPA II. Jakarta: Dirjen Dikti. Islami, M., Khaeruddin, \& Aziz, A. (2019). Pengaruh Lembar Kerja Peserta Didik (LKPD) Berbasis Inkuiri Terbimbing Terhadap Keterampilan Proses Sains Peserta Didik Kelas XI SMAN 8 Makassar. Jurnal Sains dan Pendidikan Fisika, Jilid 5, No 2, 39-49. 
Notoadmodjo, S. 2007. Pendidikan dan Ilmu Perilaku. Jakarta: PT.Rineka Cipta

Rchaeti, E., LFX, E. W., \& Padmaningrum, \&. R. (2009). Pengembangan Lembar Kerja Siswa (LKS) Untuk SMP. Jurnal Inovasi Pendidikan, Jilid 10, No 1, 62-75.

Siti Meilani. 2017. Penerapan Metode Latihan Praktikum Terbimbing 